\title{
Children's perceptions about medicines: individual differences and taste
}

\author{
Julie A. Mennella*, Kristi M. Roberts, Phoebe S. Mathew and Danielle R. Reed
}

\begin{abstract}
Background: Bitter taste receptors are genetically diverse, so children likely vary in sensitivity to the "bad" taste of some pediatric formulations. Based on prior results that variation in a bitter taste receptor gene, TAS2R38, was related to solid (pill) formulation usage, we investigated whether this variation related to liquid formulation usage and young children's reports of past experiences with medicines and whether maternal reports of these past experiences were concordant with those of their children.
\end{abstract}

Methods: We conducted retrospective interviews of 172 children 3 to 10 years old and their mothers $(N=130)$ separately in a clinical research setting about issues related to medication usage. Children were genotyped for the TASR38 variant A49P (alanine to proline at position 49). Children's responses were compared with their TAS2R38 genotype and with maternal reports.

Results: Children ( $>4$ years) reported rejecting medication primarily because of taste complaints, and those with at least one sensitive TAS2R38 allele (AP or PP genotype) were more likely to report rejecting liquid medications than were those without a taster allele (AA genotype; $x^{2}=5.72, d f=1, p=0.02$ ). Children's and mothers' reports of the children's past problems with medication were in concordance $(p=0.03)$.

Conclusions: Individual differences in taste responses to medications highlight the need to consider children's genetic variation and their own perceptions when developing formulations acceptable to the pediatric palate. Pediatric trials could systematically collect valid information directly from children and from their caregivers regarding palatability (rejection) issues, providing data to develop well-accepted pediatric formulations that effectively treat illnesses for all children.

Trial Registration: Clinicaltrials.gov protocol registration system (NCT01407939). Registered 19 July 2011.

Keywords: Children, Compliance, Genetics, Medication, Taste

\section{Background}

Most children, at some point in their lives, are given medicine to treat an illness or disease, and some will reject it. A variety of factors, including the child's age, body size, mechanics of swallowing [1], and taste preferences [2] affect acceptance of medicine. While factors inherent to the child cannot be changed, the formulation of the medicine can be. Pediatric medications come in several oral formulations (liquid, tablet or pill) and contain flavors and excipients (e.g., sweeteners), which can cater to the pediatric palate [2]. However, while solid oral dosage forms (pills) have the advantage of encapsulating

\footnotetext{
* Correspondence: mennella@monell.org

Monell Chemical Senses Center, 3500 Market Street, Philadelphia, PA 19104-3308, USA
}

(c) 2015 Mennella et al. Open Access This article is distributed under the terms of the Creative Commons Attribution 4.0 International License (http://creativecommons.org/licenses/by/4.0/), which permits unrestricted use, distribution, and reproduction in any medium, provided you give appropriate credit to the original author(s) and the source, provide a link to the Creative Commons license, and indicate if changes were made. The Creative Commons Public Domain Dedication waiver (http://creativecommons.org/publicdomain/zero/1.0/) applies to the data made available in this article, unless otherwise stated.

the taste of active pharmaceutical ingredients (so pills are less bitter and less irritating than liquids), some children have difficulty swallowing them, and fixed doses are often impractical for body-weight-based dosages. Moreover, many drugs have not been clinically tested in infants and children and thus lack appropriate pediatric formulations $[3,4]$, leading many to recognize the general need for better medicines for children worldwide.

Children cannot benefit from medicines they will not take [5]. "Taste" is often cited as a primary issue for noncompliance [5], based on a variety of questionnairebased survey and phone interview studies of parents $[6-8]$, physicians $[9,10]$, and health care personnel [9], but studies rarely asked children directly about their likes and dislikes of medications (but see ref. [11]), and 
few have determined whether mothers' reports about their children's acceptance or rejection of the medicine match those of their children. In the present study, we used a clinical research setting to separately interview directly both children and their mothers. We probed whether children can respond to open-ended questions about past experiences with medicines to determine whether their reports are concordant with those of their mothers. We also genotyped the children for a known bitter taste receptor gene but acknowledge that bitter taste is not the sole culprit of the type of bad taste of medicines, since many drugs can irritate the throat or mouth and contain unpleasant volatiles [2].

Because not all children reject medicines, genetic variation in taste receptor biology may explain some of these individual differences. During the past decade, research has reported 25 members in the TAS2R family of bitter-taste receptors [12]. These receptors are selectively sensitive to particular compounds and are genetically extremely diverse [12]. The most studied bitter taste receptor gene, TAS2R38, has several forms [13, 14]. People who are homozygous for the insensitive form (AA) typically cannot taste the bitterness of its ligands, including a medication to treat hyperthyroidism, propylthiouracil (PTU or PROP) $[13,14]$. The phenotype-genotype relationship for this receptor varies with age such that children with the bitter-sensitive genotypes (AP, PP) are more sensitive to the bitter taste of this medicine than are their parents with the same genotypes $[15,16]$. Further, recent evidence suggests that variation in bitter taste receptor genotype may be related to medication acceptance among children. That is, a retrospective analysis found that children with bitter-sensitive (homozygous PP and heterozygous AP) TAS2R38 genotypes were more likely to have taken medication in a solid formulation than were children with the bitter-insensitive (AA) genotype [17], perhaps because their bitter sensitivity makes them more motivated to take pills or tablets.

In this study, we queried a large and diverse group of children $(N=172)$ and their mothers about past experiences with medicine focusing on liquid formulations since this is the most frequently experienced formulation type taken by children of this young age group. Children were genotyped for the TAS2R38 A49P allele to test the hypothesis that variation in this bitter taste receptor gene may explain individual differences in some "taste" issues encountered in using liquid formulations and their reports of past experiences with medicines.

\section{Methods}

\section{Participants}

Participants were healthy 3- to 10-year-old children and their mothers who participated in two research studies on bitter taste perception $[15,18]$. During the telephone interview, the mothers were given detailed descriptions of the procedures for the present study but were not told the goals of the study or hypotheses being tested. Women who were diabetic, pregnant, or lactating were not eligible, and pregnancy tests were conducted on the day of testing to confirm they were not pregnant. Children who were on any medications that may alter taste sensitivity were excluded from the studies. All children were reported to be healthy by their mothers.

\section{Ethics committee approval}

All procedures were approved by the Office of Regulatory Affairs at the University of Pennsylvania, Protocol Number 809789. Written informed consent was obtained from a parent of each child, and assent was obtained from each child 7 years of age and older. The study was registered on ClinicalTrials.gov Protocol Registration System (NCT01407939).

\section{Procedures}

Mothers and children were queried separately in private testing rooms. Mothers completed questionnaires regarding demographics and race (assigned per US Census categories) and were asked individually about their child's overall medication history, including types of formulations (e.g., liquids, drops, pills or tablets, nasal sprays), flavor preferences, and past problems. Children were also asked directly and privately (in a separate testing room without the presence of the mother) about their past experiences of taking medicines: whether they were ever given medicine to drink, chew, or swallow; if so, whether there were any medicines they would not take; and if so, why they refused.

\section{Genotyping methods}

A saliva sample was collected and genomic DNA was extracted from it following the directions of the manufacturer (Oragene, DNA Genotek, and Canada). The TAS2R38 A49P alleles (rs713598; accession no. AF494231) were genotyped using dye-based primers and probes (Life Technologies, Grand Island, New York). Children were identified as bitter-insensitive homozygous (AA), bitter-sensitive homozygous (PP), or heterozygous (AP) [13]. Although there are three common variant sites in this gene, we chose to group children by the first one (A49P, rs713598) because it explains most of the individual differences in the taste response $[16,19]$ and is a proxy for other variants due to linkage disequilibrium [20]. Genotyping quality steps included assaying known control samples, assaying $10 \%$ of samples in duplicate, and establishing that genotypes were in Hardy-Weinberg equilibrium. 


\section{Statistical analyses}

All analyses were conducted using Statistica (version 12; StatSoft, USA). ANOVAs determined whether children grouped by formulation acceptance varied by age. Nonparametric analyses assessed whether there were associations 1 ) between TAS2R38 genotype and reported problems with liquid medications and 2) between responses of children and their mothers. Genetic analyses were conducted assuming a dominant model $[13,16,18]$ in which children with one or two bitter sensitive alleles were grouped and compared to children who were homozygous for the insensitive allele. Summary statistics are means \pm SEM or percentage of group.

\section{Results}

The mothers averaged $33.9 \pm 0.7$ years old $(N=130)$, and the children $(N=172)$ were between the ages of 3 and 10 years. Included in the sample were 94 singletons, 31 sibling dyads, 4 sibling triads, and 1 sibling tetrad. As shown in Table 1, children's race/ethnicity,

Table 1 Subject demographics

\begin{tabular}{|c|c|}
\hline Measure & Data \\
\hline \multicolumn{2}{|l|}{ Children $(N=172)$ : } \\
\hline Sex (girls, boys) & 97 girls, 75 boys \\
\hline Age, years $[$ mean \pm SEM $(n)]$ & $7.8 \pm 0.1(172)$ \\
\hline \multicolumn{2}{|l|}{ Race/ethnicity [\% (n)] } \\
\hline White & $12.8 \%(22 / 172)$ \\
\hline Black & $56.4 \%(97 / 172)$ \\
\hline Hispanic & $14.5 \%(25 / 172)$ \\
\hline Asian & $1.2 \%(2 / 172)$ \\
\hline Other/more than one race & $15.1 \%(26 / 172)$ \\
\hline \multicolumn{2}{|l|}{ TAS2R38, A49P genotype $[\%(n)]^{a}$} \\
\hline AA & $29.6 \%(50 / 169)$ \\
\hline AP & $45.6 \%(77 / 169)$ \\
\hline PP & $24.8 \%(42 / 169)$ \\
\hline $\begin{array}{l}\text { No. children who did not answer questions } \\
\text { regarding medication usage }[\%(n)]\end{array}$ & $11 \%(19 / 172)$ \\
\hline \multicolumn{2}{|l|}{ Non-Responders' Genotype } \\
\hline $\mathrm{AA}$ & $15.8 \%(3 / 19)$ \\
\hline $\mathrm{AP} / \mathrm{PP}$ & $84.2 \%(16 / 19)$ \\
\hline \multicolumn{2}{|l|}{ Mothers $(N=130)^{b}$ : } \\
\hline Age, years $[$ mean \pm SEM $(n)]$ & $33.9 \pm 0.7(130)$ \\
\hline \multicolumn{2}{|l|}{ Family Yearly Income, [\% (n)] } \\
\hline$<\$ 35,000$ & $62.3 \%(81 / 130)$ \\
\hline$\$ 35,000-\$ 75,000$ & $26.2 \%(34 / 130)$ \\
\hline$>\$ 75,000$ & $11.5 \%(15 / 130)$ \\
\hline Highest Education Level, college graduate, [\% (n)] & $48.5 \%(63 / 130)$ \\
\hline
\end{tabular}

${ }^{a}$ Data from 3 children were refractory to genotyping

${ }^{\mathrm{b}}$ Mothers of 94 singletons, 31 sibling pairs, 4 sibling triads, and 1 sibling tetrad family yearly income, and mothers' highest education level, based on maternal reports, reflected the racial and socioeconomic diversity of the Philadelphia area [21]. Duplicate genotyping assay results matched in every case and genotypes were in Hardy-Weinberg equilibrium $\left[\mathrm{X}_{(2)=} 2.45, p=0.29\right]$. Genotypes of three children could not be obtained even after multiple attempts.

Mothers reported that the children had last been given medication within the past $6.1 \pm 0.5$ months (range: $<1$ 36 months): cold and pain remedies (98.3\%), antibiotics (52.9\%), antihistamines (26.2\%), anti-asthmatics (11.0\%), gastrointestinal (4.7\%), antifungal (4.1\%), and psychiatric $(2.9 \%)$. All had prior experience with liquid formulations. Cherry, bubble gum, and grape were reported to be the children's favorite flavorings. Regardless of their child's age, most mothers preferred pediatric liquid formulations (63.4\%), followed by chewable tablet (19.8\%) or gummy $(9.3 \%)$ formulation (Table 2).

Not all children answered the questions. Of the 172 children, 19 (11.0 \%) did not respond when asked if they had ever refused medication (Table 1). These 19 children were significantly younger $(6.2 \pm 0.4$ years $)$ than the 153 children who did respond to the questions (8.0 \pm 0.1 years; $\mathrm{F}(1,170)=18.69 ; p<0.0001)$. The vast majority of the non-responders had bitter sensitive genotypes ( $84.2 \%$ were AP/PP; $15.8 \%$ were AA). None of the children who were younger than 4 years of age responded to the questions.

Table 2 Children's medication history as reported by Mothers ${ }^{\mathrm{a}}$

\begin{tabular}{ll}
\hline Questions & $\%(\mathrm{n} / \mathrm{N})$ \\
\hline Child has taken medications & $100 \%(172 / 172)$ \\
Liquid drops or liquids & $100 \%(172 / 172)$ \\
Chewable & $34.3 \%(59 / 172)$ \\
Nasal sprays & $18.0 \%(31 / 172)$ \\
Pills or tablets & $19.8 \%(34 / 172)$ \\
Child had problems taking medication & $48.3 \%(83 / 172)$ \\
Liquid drops or liquids & $41.9 \%(72 / 172)$ \\
Chewable & $16.1 \%(9 / 56)^{b}$ \\
Nasal sprays & $45.2 \%(14 / 31)$ \\
Pills or tablets & $32.4 \%(11 / 34)$ \\
Preferred pediatric formulation & \\
Liquid & $63.4 \%(109 / 172)$ \\
Chewable tablet & $19.8 \%(34 / 172)$ \\
Gummy & $9.3 \%(16 / 172)$ \\
Pill/tablet & $2.3 \%(4 / 172)$ \\
Strips & $1.1 \%(2 / 172)$ \\
No preference/other & $4.1 \%(7 / 172)$ \\
\hline
\end{tabular}

aff mother had multiple children in the study, she reported which formulation she most preferred for her children

${ }^{\mathrm{b}}$ Data missing for three mothers for this entry 
Of the 153 children who responded to the questions, $89(58.2 \%)$ reported refusing to take medications, and 86 (96.6\% of those who reported refusal) responded when asked why they had refused. We found motherchild concordance $(N=153$ dyads $)$ in reports of past problems taking medications $\left(\mathrm{X}^{2}=4.96, \mathrm{df}=1, p=0.03\right)$. About half of the mothers (48.3\%; Table 2) and children (58.2\%; Table 3 ) reported such problems. The primary reason children gave for rejecting medicine was "taste" complaints (Table 3).

Reports of medication compliance were related to bitter receptor genotype. More children with at least one sensitive TAS2R38 allele (AP, $N=77 ; \mathrm{PP}, N=42$ ) reported having problems accepting liquid formulations (48\% with AP/PP, $N=57 / 119$ ) than did those with no bitter alleles (28\% with AA, $N=14 / 50 ; \chi^{2}=5.72, \mathrm{df}=1$,

Table 3 Reasons given by children for refusing medications

\begin{tabular}{|c|c|}
\hline \multicolumn{2}{|l|}{ Taste/flavor, $84.9 \%$ (73/86) } \\
\hline "Nasty"/"Nasty taste" ( $n=32)$ & "Doesn't taste good" \\
\hline "Yucky" $(n=4)$ & "Taste like fish" \\
\hline "Bitter" (n=3) & "Don't like grape" \\
\hline "Tastes horrible" $(n=2)$ & "Sour/salty taste" \\
\hline "Gross/tastes gross" $(n=2)$ & "Bitter cherry/ear wax taste" \\
\hline "Tastes ugh" ( $n=2)$ & "Doesn't taste like cranberries" \\
\hline "Bad taste" $(n=2)$ & "Only like blueberries" \\
\hline "Icky taste later" & "Fruit flavor, only bubble gum flavors" \\
\hline "Nasty after taste" & "Tastes nasty, only like bubble gum" \\
\hline "Tastes old" & "Nasty, doesn't like cherry" \\
\hline "Tastes like poison" & "Tastes nasty/doesn't like color or flavor' \\
\hline "Don't like taste" & "Too hard" \\
\hline $\begin{array}{l}\text { "They have vegetables inside } \\
\text { and don't taste good" }\end{array}$ & "Mom puts it in salty water" \\
\hline "Tastes like alcohol" & "Tastes like salt water" \\
\hline "Tastes like diet" & "Tasted horrible and scared to swallow" \\
\hline "Hated taste" & "Tastes too sour, old people like them" \\
\hline \multicolumn{2}{|l|}{ "Disgusting" } \\
\hline \multicolumn{2}{|l|}{$\begin{array}{l}\text { Problems with swallowing or } \\
\text { choking, } 8.1 \%(7 / 86)\end{array}$} \\
\hline "Hard to swallow" $(n=2)$ & "Scared to choke" \\
\hline $\begin{array}{l}\text { "Couldn't swallow and } \\
\text { choked on it" }\end{array}$ & "Have to drink water to swallow them" \\
\hline $\begin{array}{l}\text { "Gag, can't chew, hard to } \\
\text { swallow" }\end{array}$ & $\begin{array}{l}\text { "Afraid because little boy on TV choked } \\
\text { from pills" }\end{array}$ \\
\hline \multicolumn{2}{|l|}{$\begin{array}{l}\text { Consequences of taking } \\
\text { medicine, } 2.3 \%(2 / 86)\end{array}$} \\
\hline "Allergic" & "Makes me have headaches" \\
\hline \multicolumn{2}{|l|}{ Combination/other, 4.7 \% (4/86) } \\
\hline "I don't know" $(n=2)$ & "I don't know what to do with them" \\
\hline "Medicine is for grownups" & \\
\hline
\end{tabular}

Responses are $n=1$, except as noted $p=0.02)$. Of those children who had been offered pills $(N=34)$, there was no difference in age between those who rejected $(8.8 \pm 0.4$ years, $N=11)$ or accepted $(8.7 \pm$ 0.3 years, $N=23)$ them $(\mathrm{F}(1,32)=0.027 ; p=0.87)$. More than half of these children were trained to take pills (58.8\%; $N=20 / 34$ ), as reported by their mothers. Onethird of these children (35\%; $N=7 / 20$ ) had problems swallowing or rejected the pills despite training. While this small sample size precludes statistical conclusions, we found that $75 \%(15 / 20)$ of children with at least one bitter-sensitive allele (AP/PP) reported having taken a solid formulation compared to $57 \%(8 / 14)$ of children with no bitter-sensitive alleles (AA).

\section{Discussion}

Based on prior results that variation in a bitter taste receptor gene, TAS2R38, was related to solid (pill) formulation usage [17], we interviewed children and their mothers separately and included questions about liquid formulation usage and memories of past experiences with medicines, and then determined if children's responses were related to their TAS2R38 genotype and with responses of their mothers. Mothers reported having problems administering all types of oral formulations to their children, and they and their children reported rejecting medications primarily for "taste" reasons. However, not all children (especially those $<4$ years old) responded to open-ended questions regarding past use of medication, highlighting limitations in collecting such information in this manner from younger children. Consistent with prior reports [10, 22-24], liquid formulations were preferred by mothers but were most reported by children as being problematic to take. Such findings reflect children's biology: research on children of the age range in the present study (3-10 years) has repeatedly revealed that they reject bitter tastes $[13,15,16]$ and avoid unpleasant flavors and textures [2] but favor sweet (pleasant) tastes [18, 25, 26]. The child's most preferred levels of sweetness and sensitivity to bitterness do not go through pronounced changes until mid-adolescence, achieving levels measured in adults [16, 26].

Some mothers attempted to train their children to swallow pills, with only moderate success. Some children voiced concerns about taking pills and fear of choking [27]. Children who had successfully taken a solid dosage form averaged 9 years of age, a finding remarkably consistent with data derived from pharmacy dispensing records in the Netherlands [4]. Like teenagers and adults, older children vary greatly in biomechanics of swallowing and ability to swallow tablets and capsules [1], despite behavioral training $[27,28]$. Therefore, offering medicines in pill form to children is only partially successful even for older children. 
Not only are some children more sensitive to bitter tastes than are adults despite similar genetics $[15,16]$, but we found that some children were genetically more sensitive than others, and such differences are related to liquid medication usage and acceptance. In the present study, children who had at least one sensitive allele (PP or AP) of the bitter taste receptor gene TAS2R38 were more likely to report rejecting liquid medications than were children with the insensitive (AA) allele, extending our previous findings that this taste genotype is associated with experience of solid medicine formulations [17]. Unlike this prior study where many of the 3- to 10-year-old children $(N=138)$ had taken medicine in solid form [17], few children $(N=34)$ in the present study had done so. Nevertheless, we have observed the relationship between TAS2R38 genotype and issues related to medications in two independent populations of children ([17]; present study). Although the TAS2R38 receptor gene is unlikely to be sensitive to all bitter compounds found in medications, its alleles may be a proxy for general taste ability [29], are related to acceptance of other bitters such as those found in vegetables [30] and are associated with individual differences in other aspects of taste biology (e.g., sweet preference) [13]. Also, because bitter taste receptor genes occur in linked clusters [31], genetic variation in this receptor may be related to variation in other receptors. Future work should also relate variation in medication acceptance among children to polymorphism of other taste receptor genes, including those related to sweet taste.

The present study focused on children's and mothers' reports of past experiences with medications, rather than assessing taste rejection or actual compliance with a specific medication. While not all children can provide information on the sensory acceptance of medications, we found concordance between reports by children and their mothers regarding medication usage, indicating both the ability of children to report on their own experiences and the reliability of their mother's reports for children who are not able to respond themselves. Children's perceptions, as well as those of their caregivers, are valuable and, as illustrated herein, highlight the formidable task faced by health professionals and parents to provide oral dosage formulations that children like or accept its taste. An estimated $40 \%$ of the world's children are at increased risk for avoidable adverse events such as suboptimal dosing and lack of adherence to medication regimens [3, 10, 32]. How much suboptimal dosing arises solely from the bad taste of medicine is unknown, but these data suggest that prospective studies are needed to understand the role of individual differences in taste acceptance of individual medicines. Our data point toward the feasibility of gathering such information from children and, for very young children, from their mothers regarding experiences with medications. However, it is important to note that for foods, mothers are more accurate in the types of foods that are disliked by their children than those that are liked [33]. Thus, it may be if one is interested in children's dislikes of particular medicines, maternal reports might be suitable but if one is interested in their likes, applying age-appropriate sensory methodologies rather than maternal reports may be more appropriate [2].

Future pediatric clinical trials thus could systematically collect data regarding taste acceptance/palatability of particular medicines directly from children and their caregivers (see [11]). Such data, combined with information on the type of formulation, types of excipients, and methods of administration [34], will help develop and validate nonproprietary methods to assess behaviors associated with concepts such as "acceptance", "rejection" and "palatability". These methods need to be sensitive to the cognitive limitations of children of varying ages (see ref. [2] for discussion). The ultimate goal is to develop well-accepted pediatric formulations that effectively treat illnesses for all children.

\section{Conclusions}

In this study, children reported rejecting medication primarily because of taste complaints, and those with at least one sensitive TAS2R38 allele (AP or PP genotype) were more likely to report rejecting liquid medications than those without a taster allele. Thus, individual differences in taste responses to medications highlight the need to consider children's genetic variation and their own perceptions when developing formulations acceptable to the pediatric palate. Mothers' and children's reports of children's past problems with medication matched, indicating that pediatric trials could systematically collect information directly from either children or their caregivers regarding issues related to acceptance or rejection of medicines, providing data to develop well-accepted pediatric formulations that effectively treat illnesses for all children.

\section{Competing interests}

The authors declare that they have no competing interest.

\section{Authors' contributions}

JAM designed the study and led data collection, analysis, and manuscript write-up; KMR and PSM collected data, analyzed data, and assisted in manuscript write-up; DRR oversaw genotyping and contributed to manuscript write-up. All authors read and approved the final manuscript.

\section{Acknowledgments}

We acknowledge the National Institute of Deafness and Other Communication Disorders (NIDCD), National Institutes of Health (NIH), for funding and support for this project (R01 DC011287, P30DC011735). The content is solely the responsibility of the authors and does not necessarily represent the official views of NIDCD or NIH, which had no input in the study design, the collection, analysis, and interpretation of data, the writing of the manuscript or the decision to submit the manuscript for publication. We acknowledge valuable discussions with Dr. George Giacoia. Two reviewers made comments which improved the quality of this manuscript. 
Received: 16 June 2014 Accepted: 9 September 2015

Published online: 21 September 2015

\section{References}

1. Ruark JL, McCullough GH, Peters RL, Moore CA. Bolus consistency and swallowing in children and adults. Dysphagia. 2002;17(1):24-33.

2. Mennella JA, Spector AC, Reed DR, Coldwell SE. The bad taste of medicines: Overview of basic research on bitter taste. Clin Ther. 2013;35:1225-46.

3. Giacoia GP, Taylor-Zapata P, Zajicek A. Eunice Kennedy Shriver National Institute of Child Health and Human Development Pediatrics Formulation Initiative: Proceedings from the Second Workshop on Pediatric Formulations. Clin Ther. 2012;34:S1-S10.

4. Schirm E, Tobi H, de Vries TW, Choonara I, De Jong-van den Berg LT. Lack of appropriate formulations of medicines for children in the community. Acta Paediatr. 2003;92(12):1486-9.

5. Nunn T, Williams J. Formulation of medicines for children. Br J Clin Pharmacol. 2005;59(6):674-6.

6. Baguley D, Lim E, Bevan A, Pallet A, Faust SN. Prescribing for children - taste and palatability affect adherence to antibiotics: a review. Arch Dis Child. 2012;97(3):293-7.

7. Dagan R, Shvartzman P, Liss Z. Variation in acceptance of common oral antibiotic suspensions. Pediatr Infect Dis J. 1994;13(8):686-90.

8. Polaha J, Dalton 3rd WT, Lancaster BM. Parental report of medication acceptance among youth: implications for everyday practice. South Med J. 2008;101(11):1106-12.

9. Steele RW, Thomas MP, Bégué RE. Compliance issues related to the selection of antibiotic suspensions for children. Pediatr Infect Dis J. 2001;20(1):1-5.

10. Milne $\mathrm{CP}$, Bruss JB. The economics of pediatric formulation development for off-patent drugs. Clin Ther. 2008;30:2133-45.

11. Matsui D. Assessing palatability of medicines in children. Paediatr Perinat Drug Ther. 2007:8:55-60.

12. Meyerhof W, Batram C, Kuhn C, Brockhoff A, Chudoba E, Bufe B, et al. The molecular receptive ranges of human TAS2R bitter taste receptors. Chem Senses. 2010;35(2):157-70.

13. Mennella JA, Pepino MY, Reed DR. Genetic and environmental determinants of bitter perception and sweet preferences. Pediatrics. 2005;115(2):e216-222.

14. Drayna D, Coon H, Kim UK, et al. Genetic analysis of a complex trait in the Utah Genetic Reference Project: a major locus for PTC taste ability on chromosome $7 \mathrm{q}$ and a secondary locus on chromosome 16p. Hum Genet. 2003; 112:567-72.

15. Mennella JA, Reed DR, Roberts KM, Mathew PS, Mansfield CJ. Age-related differences in bitter taste and efficacy of bitter blockers. PLoS One. 2014;9(7):e103107.

16. Mennella JA, Pepino MY, Duke FF, Reed DR. Age modifies the genotype-phenotype relationship for the bitter receptor TAS2R38. BMC Genet. 2010;11:60.

17. Lipchock SV, Reed DR, Mennella JA. Relationship between bitter-taste receptor genotype and solid medication formulation usage among young children: a retrospective analysis. Clin Ther. 2012;34:728-33.

18. Mennella JA, Reed DR, Mathew PS, Roberts KM, Mansfield CJ. "A spoonful of sugar helps the medicine go down": Bitter masking by sucrose among children and adults. Chem Senses. 2015;40:17-25.

19. Bufe B, Breslin PA, Kuhn C, Reed DR, Tharp CD, Slack JP, et al. The molecular basis of individual differences in phenylthiocarbamide and propylthiouracil bitterness perception. Curr Biol. 2005;15(4):322-7.

20. Kim UK, Jorgenson E, Coon H, Leppert M, Risch N, Drayna D. Positional cloning of the human quantitative trait locus underlying taste sensitivity to phenylthiocarbamide. Science. 2003;299(5610):1221-5.

21. Pew Charitable Trust. Philadelphia: The State of the City, a 2014 Update. Philadelphia, PA 2014. Available at: http://www.pewtrusts.org/ en/research-and-analysis/reports/2014/04/05/philadelphia-the-state-ofthe-city-a-2014-update. Accessed 28 April 2015.

22. Thomson SA, Tuleu C, Wong IC, Keady S, Pitt KG, Sutcliffe AG. Minitablets: new modality to deliver medicines to preschool-aged children. Pediatrics. 2009;123(2):e235-238.

23. Allen LVJ. Dosage form design and development. Clin Ther. 2008;30(11):2102-11.

24. EMEA/CHMP/PEG/194810/2005 (2006) Reflection paper: formulations of choice for the paediatric population. London: EMEA (2006). Available at: http://www.ema.europa.eu/docs/en_GB/document_library/Scientific_ guideline/2009/09/WC500003782.pdf. Accessed 28 April 2015.
25. Mennella JA, Finkbeiner S, Lipchock SV, Hwang LD, Reed DR. Preferences for salty and sweet tastes are elevated and related to each other during childhood. PLoS One. 2014;9:e92201.

26. Mennella JA, Lukasewycz LD, Griffith JW, Beauchamp GK. Evaluation of the Monell forced-choice, paired-comparison tracking procedure for determining sweet taste preferences across the lifespan. Chem Senses. 2011;36(4):345-55.

27. Czynewski DI, Runyan DR, Lopez MA, Calles NR. Teaching and maintaining pill swallowing in HIV-infected children. AIDS Read. 2000;10:88-94.

28. Ghuman JK, Cataldo MD, Beck MH, Slifer KJ. Behavioral training for pillswallowing difficulties in young children with autistic disorder. J Child Adolesc Psychopharmacol. 2004;14(4):601-11.

29. Bartoshuk LM, Duffy VB, Reed D, Williams A. Supertasting, earaches and head injury: genetics and pathology alter our taste worlds. Neurosci Biobehav Rev. 1996;79:87.

30. Bell Kl, Tepper BJ. Short-term vegetable intake by young children classified by 6-n-propylthoiuracil bitter-taste phenotype. Am J Clin Nutr. 2006;84(1):245-51.

31. Adler E, Hoon MA, Mueller KL, Chandrashekar J, Ryba NJ, Zuker CS. A novel family of mammalian taste receptors. Cell. 2000;100(6):693-702.

32. Rakhmanina NY, van den Anker JN. Pharmacological research in pediatrics: From neonates to adolescents. Adv Drug Deliv Rev. 2006;58(1):4-14.

33. Liem DG, Zandstra L, Thomas A. Prediction of children's flavour preferences. Effect of age and stability in reported preferences. Appetite. 2010;55(1):69-75.

34. Standing JF, Khaki ZF, Wong IC. Poor formulation information in published pediatric drug trials. Pediatrics. 2005;116(4):e559-562.

\section{Submit your next manuscript to BioMed Central and take full advantage of:}

- Convenient online submission

- Thorough peer review

- No space constraints or color figure charges

- Immediate publication on acceptance

- Inclusion in PubMed, CAS, Scopus and Google Scholar

- Research which is freely available for redistribution 